\title{
Perspectives on the impact of the COVID-19 pandemic on the global and African maritime transport sectors, and the potential implications for Africa's maritime governance
}

\section{Adekola Oyenuga $^{1}$}

Received: 10 December 2020 / Accepted: 10 March 2021 / Published online: 6 April 2021

(C) World Maritime University 2021

\begin{abstract}
The maritime transport sector (MTS) has been impacted by the coronavirus 2019 pandemic, with significant disruptions to shipping and maritime activity along established transport routes. This paper examines the impacts of the pandemic on the MTS, at the global and African levels, and discusses what Africa's priorities for its MTS should be in the post-pandemic era. The short-term impacts of the pandemic are identified as including a drop in the volume of trade transported by maritime shipping; disruptions due to re-routed shipments; maritime defaults and bankruptcies; and stranded seafarers. To understand the longer-term impacts, the paper analyzes the pandemic's effect on five critical trends facing the MTS globally, viz, trade tensions, geopolitical developments, structural disruptions, regulatory pressures, and environmental incidents. In the African context, the paper highlights that with a mere $4 \%$ share of global container port traffic and a $7 \%$ and $5 \%$ share, respectively, of international maritime exports and imports (measured by tonnage), Africa's significance to the global MTS is not huge. Hence, an impact analysis based on the global MTS trends would be premature. The paper concludes that Africa's MTS in the post-pandemic era should focus on improving operational performance and sustainable development. Africa should also improve maritime governance to ensure that desired developmental outcomes are realized. It is argued that adopting a multi-stakeholder governance framework will be most appropriate for the continent's MTS in the post-pandemic era. Further research is however needed to identify how a multi-stakeholder governance framework should be adapted and deployed to fit different African environments.
\end{abstract}

Keywords Africa $\cdot$ Covid-19 $\cdot$ Maritime governance $\cdot$ Maritime transport sector $\cdot$ Multistakeholder governance

Adekola Oyenuga

adekola.oyenuga@aobeec.com

1 AO Blue Economy \& Energy Consulting, Nyjordstubben 156, 1275 Oslo, Norway 


\section{Introduction}

Maritime shipping transports more than $80 \%$ of world trade, including vital medical supplies, food, and other basic goods (United Nations 2020). ${ }^{1}$ This is confirmed by the World Bank Group (Humphreys et al. 2020). The global maritime transport sector (MTS) has however been significantly impacted by the coronavirus 2019 (COVID-19) pandemic. March et al. (2020) utilize electronic data from maritime vessels' Automatic Identification Systems (AIS) to show sustained disruptions and regional slowdowns in shipping, amounting to several weeks, along established transport routes in Asia, Africa, and Europe. ${ }^{2}$

Notteboom and Pallis (2020) identify in the IAPH-WPSP Port Economic Impact barometer survey (July 2020) that approximately $33 \%$ of surveyed ports reported a decline in the number of port calls made by container vessels of 5-25\% compared with a normal situation $^{3}$ (this decline actually represented an improvement on the $45 \%$ decline reported between late May and mid-June 2020 and the 38-39\% decline reported in early April). Of the surveyed ports, $16 \%$ reported declines (in excess of 25\%) in port calls made by other cargo vessels relative to a normal situation. Fortunately, the situation for container and other-cargo vessels is by now gradually returning to normal (pre-COVID-19) levels, even though roll-on-roll-off (Ro-Ro) and cruise shipping remain strongly impacted.

Due to fears that shipping crews could become unwitting vectors enabling the international transmission of the virus, normal procedures for granting shipping crews' access to ports were widely disrupted (e.g., for shore-leave, family reunions, repatriations or even for health purposes, and to be replaced by new crews). As a result, several seafarers have been stranded aboard their vessels for prolonged periods and unable to disembark or to reunite with their families. This has imposed additional economic and safety costs on the shipping industry, and has also imposed humanitarian, health, and psychological costs on individual seafarers.

The International Chamber of Shipping and the International Transport Workers Federation estimated (as at 4 September 2020) that more than 300,000 seafarers and marine personnel remained on board commercial vessels, unable to be repatriated and past the expiry of their contracts (International Maritime Organization 2020). ${ }^{4}$

\subsection{Emergence and international spread of COVID-19}

The World Health Organization (WHO) became aware of COVID-19 through a media statement addressing cases of "viral pneumonia" in Wuhan, China. This statement was published by the Wuhan Municipal Health Commission at the end of December 2019 (WHO 2020a) ..$^{5}$ By the time the new year dawned in 2020, the disease was well on its way beyond China's borders.

\footnotetext{
${ }^{1}$ Cited in a statement attributable to the Spokesman for the Secretary-General on the repatriation of seafarers, 12 June 2020. See reference section for details.

${ }^{2}$ Although they note that not all changes observed in their assessment were necessarily related to COVID-19.

${ }^{3}$ Based on a global survey by the International Association of Ports and Harbours and the World Ports Sustainability Program (IAPH-WPSP) of 90 ports spanning Africa, South East and North Asia, North America, Middle East and Central Asia, Europe, and Central and South America.

${ }^{4}$ Source: Statement by the IMO Secretary General on 4 September 2020.

${ }^{5}$ Source: Timeline of WHO's response to COVID-19. See Reference section for further details.
} 
The first international case of COVID-19 was reported by the Ministry of Public Health of Thailand on 13 January 2020. Soon afterwards, on 16 January, a second case (attributable to an individual who had recently travelled to Wuhan) was reported by the Japanese Ministry of Health, Labour and Welfare. In the Americas, the first case was confirmed in the USA on 21 January, while the first European occurrence was recorded with three French cases on 24 January. In the Middle East and eastern Mediterranean region, the United Arab Emirates (UAE) reported their first case on 29 January. By 30 January, the rapid international spread of COVID-19 informed the WHO's decision to declare the disease a Public Health Emergency of International Concern (PHEIC).

By February 4, 99\% of all confirmed cases were within China, with only 176 cases documented internationally. The disease was at this point viewed by the WHO to be: "first and foremost an emergency for China" (WHO 2020b) ${ }^{6}$. However, the accelerating international spread of the disease and its increasing severity eventually compelled the WHO to characterize the disease as having achieved pandemic proportions on 11 March. By this time, the epicenter of the disease had relocated from China to Europe, therewith transforming the erstwhile "Chinese emergency" into a full-fledged global crisis.

Initial attempts at containing the spread of COVID-19 in Asia led to the introduction of screening procedures at Asian ports, mainly in South Korea, Taiwan, and Singapore and the quarantining of Chinese shipping crews. The Chinese authorities also imposed a nationwide ban on non-essential travel and ordered the closure of production and shipbuilding facilities. Consequently, capacity utilization at the largest Chinese ports fell by $20-50 \%$ with a sharp increase being recorded in the use of port storage facilities (Berti 2020). ${ }^{7}$

The measures implemented to curb the spread of COVID-19 in China had a significant, albeit negative impact on Chinese exports, and that cascaded into a contraction in China's economy. Another impact of these measures was a sharp drop in Chinese demand for commodity imports such as crude oil. This has meant that China's domestic response to COVID-19 generated negative ripple effects which have impacted the global stage, and which may persist for some time to come.

\subsection{Africa's response to the international spread of COVID-19}

On the African continent, the first confirmed case of COVID-19 was recorded in Egypt on 14 February, while the second case was reported by the Algerian Ministry of Health, Population and Hospital Reform on 25 February (WHO Africa 2020a). ${ }^{8}$ Nigeria reported the first confirmed case in Sub-Saharan Africa on 27 February. As the pandemic's spread and impact accelerated across the globe, African governments and maritime authorities intervened using diverse measures and policies to mitigate its spread within their respective countries. These interventions have been broadly effective at reducing the rate of the pandemic's spread and at ensuring that operations within

\footnotetext{
${ }^{6}$ Source: WHO DG's remarks during the 146th session of the Executive Board. The statistic cited here clearly refers to confirmed cases, as the possibility for asymptomatic transmission of the virus was at that point still the subject of ongoing studies.

${ }^{7}$ Source: Berti, A., 2020. Ship-technology.com.

${ }^{8}$ Source: WHO Africa, 25 February 2020.
} 
the MTS experience minimal interruptions under the pervading circumstances (WHO Africa 2020b). ${ }^{9}$

In Nigeria, for example, several seaports were closed with few exceptions (notably those in Lagos State) which remained operational due to their being designated as providers of "essential services." The maritime regulator, the Nigerian Maritime Administration and Safety Agency (NIMASA 2020), announced on March 29 that only international vessels that had planned and informed Nigerian port authorities about port calls (not later than 1February 2020) may be allowed to proceed with such a call ${ }^{10}$. Furthermore, vessels and crews with a history of visiting COVID-19 affected countries since 1 February 2020 were not allowed into Nigerian ports between 30 March and 12 April 2020. ${ }^{11}$

South Africa, by 20 April 2020, closed two of its eight seaports (Saldanha Bay and Mossel Bay) to passenger traffic or disembarking crews. It however opted not to restrict the import or export of goods cargoes. Kenya in contrast did not close any of its seaports, but rather allowed them to continue functioning albeit with reduced capacities. ${ }^{12}$ Similarly, Ghana's seaports were kept open to ensure the continued flow of goods imports and exports from the country. Ghanaian seaports also granted rent free storage to shippers who were unable to clear their consignments from the ports during a 3-week long partial lockdown of Accra and Kumasi due to the pandemic (Ports Management Association of West and Central Africa 2020). ${ }^{13}$

\subsection{A sample of published opinions on the impacts of COVID-19 on the global MTS}

As the COVID-19 pandemic waxes and wanes across the globe, the international MTS is slowly and painfully, struggling to re-stabilize itself and to restore some measure of operational normalcy. Opinions on the short-to-medium term impacts of COVID-19 on the MTS are not in short supply. For example, Ralby (2020) argues that COVID-19 is inducing five short-term changes in the MTS which are the following: a drop in the volume of trade transported by maritime shipping due to a global economic recession or contraction; route disruptions as shipments that are normally transported as air cargoes are re-routed through maritime transport alternatives; a decline in maritime shipments of crude oil concurrent with major increases in on-the-water oil storage caused by drops in both crude oil demand and price; a growing number of vessel defaults and maritime bankruptcies; and problems with crew changes on vessels. ${ }^{14}$

\footnotetext{
${ }^{9}$ The WHO recently commended the government of South Africa (which with a cumulative 653000 cases still accounts for nearly half of all cases in Africa) for its determined efforts that have helped to bend the COVID-19 pandemic curve (see WHO Africa, 17 September 2020). To tackle the pandemic South Africa took decisive steps such as instituting response coordination mechanisms at all levels, setting up control interventions for all critical pillars of response and imposing public health and social measures, including movement restrictions, curfews, and closure of businesses, schools, and places of worship. These strong public health measures helped to limit the exponential spread of the COVID-19 pandemic and allowed the country to establish capacities for testing, isolation, and treatment of cases and tracing and quarantine of contacts. Over the past weeks, new COVID-19 infections have been declining in South Africa. Similar positive trends are evident in other parts of Africa.

${ }^{10}$ Observe that the use of "may" as against "would" in the announcement was impliedly intended to communicate that the granted permission to access the port was not final and could be rescinded.

${ }^{11}$ Source: NIMASA's COVID-19 Communique, 29 March 2020.

12 Source: Article on ICLG.com, published 20 April 2020.

${ }^{13}$ Source: Interview of the Chairman of the Ports Management Association of West and Central Africa (PMAWCA), published on 26 June 2020.

${ }^{14}$ Source: See article by I.M. Ralby 2020, on www.diplomaticourier.com.
} 
The slowdown of the Chinese economy and the temporal closures of its maritime gateways, due to the pandemic, have also been disruptive to global supply chains. Baldwin and Weder di Mauro (2020) note that "China really is the workshop of the world, being central to the entire global network. So a manufacturing disruption there will create secondary supply shocks in manufacturing sectors in almost all nations."15 China is also a major importer of global commodities, so a contraction in its import demand will create a knock-on demand shock on the global commodity markets. Since maritime shipping is responsible for moving up to $80 \%$ of global trade, the simultaneous impact of these supply and demand shocks, compounded by China's closure of its maritime gateways, albeit temporally, will affect regional and global maritime shipping.

McKibbin and Fernando (2020) note that "Amidst the slowing down of the Chinese economy with interruptions to production, the functioning of global supply chains has been disrupted. Companies across the world, irrespective of size, that are dependent upon inputs from China have started experiencing contractions in production. Transport being limited and even restricted among countries has further slowed global economic activities." 16 Baldwin and Tomiura (2020) similarly observe that "The combination of the US' ongoing trade war against all of its trading partners (especially China) and the supply chain disruptions that are likely to be caused by COVID-19 could lead to a push to repatriate supply chains." A lesson for global supply chains being that: "Exclusively depending on suppliers from any one nation does not reduce risk - it increases it." And as a remedy, they propose: "Redundant dual sourcing from multiple countries to alleviate the problem of excess dependence on China, though with additional costs."17

Turner (2020) highlights the difficulties currently being encountered by port authorities, in Europe and worldwide, in enforcing compliance with maritime environmental regulations such as the MARPOL Convention governing the pollution potential of ships. ${ }^{18}$ The enforcement of such legislations is reportedly being sidelined as ports authorities prioritize health and the movement of freight over compliance inspections. Indeed, the pandemic may be compelling the emergence of a wider trend that has port state and coastal maritime authorities, particularly in developing countries, redirect scarce resources away from other critical areas into addressing the shorter-term demands of the current crisis. Prins (2020) argues that "The medical and economic fallout from the coronavirus pandemic seems likely to pose severe challenges for countries with few resources and weak governments. West African and South American countries already struggle to police their territorial waters. As hospitals fill with COVID-19 patients, the regions' governments will almost certainly shift their public safety efforts away from sea-based concerns such as piracy, towards more immediate concerns on

\footnotetext{
15 See p.15, by Baldwin and Weder di Mauro 2020.

16 See p. 45 in McKibbin and Fernando 2020.

${ }^{17}$ See pp. 68-69 in Baldwin and Tomiura 2020.

18 The Marpol Convention governs the pollution potential of ships; Annex VI sets progressively stricter regulations to control vessel emissions, including sulphur oxides (SOx) and nitrous oxides (NOx). Implemented on 1 January 2020, Regulation 14.1.13 of Marpol Annex VI states that sulphur content of marine fuel used on ships must be reduced from $3.5 \%$ mass by mass $(\mathrm{m} / \mathrm{m})$ to $0.50 \% \mathrm{~m} / \mathrm{m}$ for all vessels not fitted with exhaust gas cleaning systems (EGCS), or scrubbers. In parallel, SOx emissions are controlled in Emission Control Areas (ECAs) to stop the use of fuel with a sulphur content in excess of $0.10 \%$. The horizon issue is the Carriage Ban, effective on 1 March, which prevents any ship not fitted with an EGCS from carrying marine fuel with a sulphur content in excess of $0.50 \% \mathrm{~m} / \mathrm{m}$ for use on board. Source: See Turner (2020).
} 
land." This may provide an explanation for why 2020, as of May 15, had witnessed a $24 \%$ increase in pirate attacks compared with the same period in $2019 .{ }^{19}$

While the shorter-term perspectives on the impacts of the pandemic on the MTS are relatively straightforward to identify, the longer-term impacts do not lend themselves to similarly easy inference. The objective of this paper is to identify these longer-term impacts and to apply them to the African context. The narrative in the next sections will therefore rely on developing an accurate and nuanced understanding of the longer-term impacts of COVID-19, and the extent to which it may alter the operational environment within the MTS. We will start by identifying and describing a vector of critical trends facing the MTS pre-COVID-19, and how this trend vector may be affected in the postpandemic period. We will then advance the narrative to discuss the imperatives for Africa's MTS in the post-COVID-19 era and the role of maritime governance.

The rest of the paper is structured as follows: Section 2 identifies five critical trends facing the MTS prior to the pandemic. Section 3 examines the impacts of the pandemic on these trends - both globally and in an African context. Section 4 raises a question about the significance of Africa's MTS in the global picture, while Section 5 discusses some important steps to be taken by Africa's MTS in the pandemic's wake. Section 6 delves into the role of maritime governance in the post-COVID era and provides some insights into identifying an appropriate maritime governance framework for the African context. Section 7 then concludes.

\section{Five critical trends facing the global MTS prior to COVID-19}

UNCTAD (2019) reported that international maritime trade witnessed a marked slowdown in growth from 4.1 to $2.7 \%$ between 2017 and 2018. This decline affected the maritime cargo, port cargo handling, and containerized port segments (it also predicted an improved growth rate of 3.5\% between 2019 and 2024, buoyed by anticipated expansions in the containerized dry bulk and gas cargo segments). Despite its largely up-beat prognosis, UNCTAD noted that "Uncertainty remains a significant and overriding theme in the current maritime transport environment with risks tilted to the downside."

Five critical trends facing the global MTS prior to COVID-19 were the following: heightened global trade tensions; adverse geopolitical and country-specific developments; disruptions in the maritime transport industry's value chain and business models; regulatory pressures; and pressures induced by the occurrence of environmental incidents and an increase in pro-environment activism. Explanations of these trends are provided below.

\subsection{Heightened global trade tensions}

The heightened state of trade tensions between China and the USA, the two largest economies in the world, and their reciprocal imposition of trade tariffs (in 2018 and 2019) has had a dampening effect on the level of global trade between them and the volume of maritime transport capacity required to support this trade. "Trade between

$\overline{19}$ Source: see article by Prins B., 2020, published by World Economic Forum (WEF). 
China and the United States is estimated to have declined by over 15\% since September 2018, following the second round of tariff hikes. This has had an impact on global value chains and other trading partners" (UNCTAD 2019).

Not dissimilar effects, albeit on a lesser scale, were predicted owing to uncertainties in the ongoing Brexit negotiations between the UK and the European Union. In the Brexit case, however, a mitigating factor is that the anticipated reduction in the transited volume of goods between the UK and the EU will not be entirely borne by the MTS, owing to the multiplicity of bulk transit options between both sides.

\subsection{Adverse geopolitical and country-specific developments}

The current international economic sanctions imposed on the Islamic Republic of Iran and the Bolivarian Republic of Venezuela, both of which are significant exporters of crude oil, have impacted the utilization of ocean tankers to and from both countries. Furthermore, heightened risks associated with maritime transport through the Strait of Hormuz, close to Iran, and the Gulf of Aden, close to Yemen, have increased pressure on maritime traffic in the Persian Gulf and (potentially) through the Red Sea-Suez Canal route.

A number of developments occurring at the country level have also contributed towards reducing the volume of global maritime traffic. In sub-Saharan Africa where exports are predominantly commodity based, falling global prices for crude oil have resulted in reduced crude oil tanker-based exports from countries like Nigeria. This effect has been exacerbated by compliance with production cuts imposed by the Organization of Petroleum Exporting Countries (OPEC). In the case of Nigeria, the reduced level of crude oil exports has been somewhat compensated for by an increase in export shipments of liquified natural gas due to increased global demand for natural gas.

The importance of China to the international MTS is difficult to overstate. UNCTAD (2019) notes that: "the outlook for maritime trade is highly dependent on developments taking place in the Chinese economy." In fact, nearly half of global maritime trade expansion over the past decade was attributed to China, and in 2018, maritime imports into China accounted for about a quarter of maritime trade and half of dry bulk commodity trade. China is also a key player in containerized trade, given its role as the factory of the world. ${ }^{20}$

Prior to COVID-19, a Chinese economic slowdown had been predicted due to several reasons. These included the attritive effect of the ongoing trade tensions with the USA and the result of China's domestic reforms that are intended to make its economy more self-reliant and to re-orient from an erstwhile manufacturing and industrial focus to a more service and consumer-spending oriented one. As a result, there was a weakened demand for imported inputs to manufacturing and industrial processes and a reduced output of manufactured exports and, thence a decrease in China's demand for international maritime transport.

\subsection{Structural disruptions in the maritime industry}

Also prior to COVID-19, the global maritime industry was under the influence of different pressures that were individually and collectively compelling a change in its

${ }^{20}$ See UNCTAD 2019, p. 22. 
structure. These pressures included the following: technology drivers that were promoting a shift from manned maritime vessels ships to autonomous or remotely piloted vessels; advances in maritime digitization making previously only-imagined technology interventions feasible; the increasing regionalization of maritime traffic to the detriment of the globalized transport of maritime cargo; and consolidation in the ownership and operation of maritime carriers and ports alongside the introduction of new business models with restructured supply chains.

An eventual shift from conventionally manned to autonomous or "personnel lite" marine vessels and the increased digitization of operations processes for marine vessels, both offshore and in-port, could radically upend the manpower requirements of the sector. Not only would it mean that the current stock of seafarers could be made structurally redundant, but the replacements would require a significantly different skillset, implying that even the seafarer training system would also need to adapt. One notable effect of the digitization trend within the maritime industry was the formation in 2019 of the Digital Container Shipping Association (DCSA). This is a shipping platform comprised of leading maritime carriers, tasked with developing a common block-chain technology-based standard to accelerate the digitalization of container shipping, and to promote the efficient, transparent and secure exchange of information within the industry. ${ }^{21}$

The increasing regionalization of maritime transport is an offshoot of a related and leading trend towards the regionalization of supply chains and international trade flows. If unabated, one implication for the MTS would be a gradual shift in the composition of the maritime carriers' fleets, away from larger vessels (more suited to globalized freight) towards smaller and more flexible vessels that can respond more efficiently (and at lower costs) to the dynamics of regional markets. Another implication of increased regionalization in the MTS is that the current, relatively uniform dominance of the industry by large global carriers could weaken, creating opportunities for smaller actors, particularly in developing countries, to gain a foothold within their respective regions and thereby (perhaps) to emerge on the global scene.

Alix Partners (2019) noted that the pre-COVID-19 maritime transport environment of "volatile fuel costs, rising leverage and unpredictable developments on the global trade front," presented carriers with a stark strategic choice. This choice being between whether to continue to increase their fleet capacities and vessel sizes in order to reap the resulting cost efficiencies from the newer vessels, as against refocusing their fleets with smaller average vessels which would be more advantageous should global trade disruptions, prompt shifts in trade patterns. The rationale behind smaller and more flexible fleets being that these would be able to respond more quickly to changes in shippers' supply networks.

One of the signs that maritime carriers recognize ongoing disruptions in the MTS and have already begun to respond to these is a rise in consolidation (vertical integration) across the sector's supply chain. A number of carriers are integrating their business models into the so-called third-party logistics (3PL) industry by expanding "upstream" and "downstream" in the value chain. An example of this is a maritime carrier's expansion into "landside" or "multimodal" operations by acquiring warehousing, trucking, and container equipment maintenance assets, and vice versa (Alix Partners 2019).

\footnotetext{
$\overline{{ }^{21} \text { See King 2019, and Waters } 2019 .}$
} 
A.P. Moller-Mærsk, the world's biggest commercial shipping operator, has officially announced its intention to focus more on inland logistics, by acquiring onshore warehouses, container terminals, and customs brokerage firms. This is part of the organization's strategic drive to diversify its corporate earnings from the current situation where $80 \%$ of revenue arise from container shipping, to a scenario in which $50 \%$ of revenues are derived from ocean services and the balance from non-ocean services (Lloyds Shipping List 2019). ${ }^{22}$ Other carriers and investors are anticipated to follow Mærsk's lead.

\subsection{Regulatory pressures}

There were a number of international maritime regulations scheduled to be implemented by the maritime transport industry prior to COVID-19. These included the IMO's MARPOL 2020 regulation to cap sulphur emissions from ships, the 2004 International Convention for the Control and Management of Ships' Ballast Water and Sediments which entered into force in 2017, and the International Convention on Liability and Compensation for Damage in Connection with the Carriage of Hazardous and Noxious Substances by Sea, 1996, as amended by the 2010 Protocol thereto (which is yet to enter into force). The entry into force and enforcement of these conventions will impose additional and, perhaps, significant costs on the maritime transport industry.

For example, the MARPOL 2020 regulation requires that sea-going vessels utilize only climate friendly fuels with reduced sulphur-emitting properties. The costs imposed on shippers by the regulation ranges from the capital and operating costs of installing and subsequently maintaining the scrubbers on vessels, to the alternate costs of purchasing MARPOL compliant fuel and the price volatility associated with the adequate availability of these fuels. A third alternative would be for vessels to shift to a low emission fuel such as liquefied natural gas (LNG). Non-compliance could result in vessels being detained by port state inspection authorities.

Alix Partners (2019) notes that the implementation of the MARPOL 2020 regulations will pose "a daunting challenge" for carriers, while Alix Partners (2020) adds that the very survival of some of these carriers will "depend on their ability to pass their higher fuel costs along to their customers." For Port State Authorities, the additional costs from these regulations may arise in the form of their developing new inspection procedures to oversee their implementation and enforcement in the case of noncompliance, training inspection personnel in the new procedures, and the additional cost-of-time required for the inspections.

These costs may have the negative effect of making otherwise seaworthy vessels too expensive to operate and may worsen the economic situation of cash-strapped Port State Authorities. On a positive and perhaps unintended note, this may also have the effect of reducing the excess supply of shipping capacity currently evident in the sector.

\subsection{Environmental incidents and the rise of pro-environment activism}

The economic, social, and political pressures induced by the occurrence of environmental incidents such as oil spills, maritime storms, and hurricanes are having a

\footnotetext{
${ }^{22}$ See report on Wall Street Journal interview with Mærsk CEO Mr. Søren Skou published by Lloyds Shipping List on 01 July 2019.
} 
disrupting impact on the MTS. Recent examples of such incidents include the following: a bunker fuel oil spill (which may either have emanated from a Portuguese flagged vessel or from an oil pipeline), that affected the Falcon wetlands and Morrocoy National Park of Venezuela in August 2020, both of which are protected marine areas. $^{23}$ An oil spill from the Japanese-owned MV Wakashio near to environmentally protected marine ecosystems and a marine park reserve in the coastal areas of southeast Mauritius in July 2020. ${ }^{24}$ The Norilsk oil spill above Russia's Arctic circle in late May 2020, which is reportedly the worst accident of its kind in modern times in Russia's Arctic region. ${ }^{25}$ And a heavy oil spill from a Greek-flagged vessel in Venezuelan waters in September 2019, which is believed to have impacted about $2500 \mathrm{~km}$ of coastline including marine life and popular beaches in north eastern Brazil. ${ }^{26}$

While oil spills are most likely a direct result of human error and/or operational negligence, marine storms and hurricanes are arguably the indirect offshoots of degenerative human or anthropogenic influences on the earth's climate and natural capacity for resilience. Either way, as the argument goes, the sustainability of human life on the planet, as we know it, may be in question. It is in response to such an argument that there is a heightened level of interest being paid (typically driven by voluntary commitments as against regulatory compulsion) not just to having the MTS "cleanup-its-act" as a contributor to environmental incidents and problems, but also towards its playing a leadership role in defining and promoting solutions that will usher in a more sustainable future for the environment and planet.

International initiatives such as the UN Global Compact's Sustainable Ocean Business Action Platform ${ }^{27}$, the High-Level Panel for a sustainable ocean economy ${ }^{28}$, or the International Chamber of Shipping's Vision for Zero Carbon Shipping Future ${ }^{29}$ are instances of "pro-environmental activism" that have implications for the MTS' future development.

\section{How has COVID-19 affected the critical trends facing the MTS?}

As COVID-19 has impacted the global economy and maritime sector, it has also affected the critical trends facing the MTS. We will examine these effects in turn in this section.

\subsection{The effect on heightened global trade tensions}

Generally, COVID-19 has had the effect of exacerbating the impact of already existing global trade tensions. It has induced a global economic recession that has further reduced trade between the USA and China and has re-inforced pressures to restructure

\footnotetext{
${ }^{23}$ See BBC.com (2020a).

${ }^{24}$ See BBC.com (2020b).

25 See BBC.com (2020c).

${ }^{26}$ See BBC.com (2019).

${ }^{27} \mathrm{See}$ https://www.unglobalcompact.org/take-action/action-platforms/ocean.

${ }^{28}$ See https://www.oceanpanel.org/.

${ }^{29}$ See https://www.ics-shipping.org/news/press-releases/2017/11/06/un-climate-conference-ics-has-visionfor-zero-carbon-shipping-future.
} 
global supply chains emanating in Asia. China now exports manufacturing inputs to other Asian countries, such as Vietnam and Indonesia, for final assembly and export to the USA in other to evade the tariffs. Asia's rapid recovery from the COVID-19 recession has led to a strengthening of regionalization trends in Asian trade, to the detriment of global trade (Dollar and Newby 2020).

Although the UK is yet to formally request for an extention to the Brexit negotiations, one likely effect of COVID-19 will be to extend the process. The economic disruptions caused by COVID-19 coupled with the uncertainties from Brexit are expected to increase the overall level of uncertainty within the MTS. Future COVID19 outbreaks that overlap with the end of the Brexit transition period, as new border controls and customs processes are introduced between the UK and Europe, may further increase uncertainty while disrupting supply chains that up till now have remained largely resilient (Christie 2020).

African countries have experienced economic difficulties due to the US-China trade war. This is because the US tariffs have precipitated drops in commodity prices, local currencies, and major stock exchanges.

Pre-COVID-19, the African Development Bank (AfDB) warned that global trade tensions could cause a $2.5 \%$ GDP reduction in resource-intensive African countries and a $1.9 \%$ reduction for oil exporters by 2021 . The International Monetary Fund (IMF) similarly lowered Africa's growth projections from 3.3 to $3.1 \%$ in 2019 , citing rising trade tensions, Brexit, and slowing Chinese growth as explanations. It further warned that the trade war could alone cause up to a $1.5 \%$ cumulative drop in Africa's GDP growth by 2021. These effects have merely been strengthened by COVID-19 (Devermont and Chiang 2019).

\subsection{The effect on adverse geopolitical and country-specific developments}

Indications show that COVID-19 has worsened the already severe impact of the sanctions imposed on Iran. What was previously mainly an economic crisis has now escalated into a healthcare and economic one. It is however not clear the extent to which a weakened Iran (in the aftermath of COVID-19) may be less/ more of a geopolitical gadfly to maritime activity in the strait of Hormuz. A destabilized and impoverished Iranian regime, facing the risk of regime change, may indeed become a more volatile and unpredictable actor on the foreign policy front (Djavad 2020).

As in the case of Iran, COVID-19 has worsened an already complex economic, social, and humanitarian situation in Venezuela (Rendon and Sanchez 2020). With the continuation of US sanctions on the export of Venezuela's crude oil, it is doubtful whether Venezuela - which is already in an internally weakened and destabilized state will be able to create (or sustain) regional geopolitical tensions through its foreign policy (Yao and Crossley 2020). With regard to Africa, heightened uncertainty in the availability of oil and gas exports from Iran and Venezuela following COVID-19 may push-up hydrocarbon prices, which will be beneficial for Africa's hydrocarbon exporters such as Nigeria and Angola.

Following a deep slump in Q1 2020, China's economy returned to growth in Q2 2020. China's Q2 GDP grew by $3.2 \%$ compared with the preceding year and exceeded 
a $2.5 \%$ forecast. However, the possibility of a COVID-19 resurgence, global economic instability, and the state of China-US trade relations will continue to feed uncertainty.

China is Africa's largest trading partner and the slump in China's economy due to COVID-19 has been bad for Africa. Trade between China and Africa fell by $14 \%$ to $\$ 41$ billion in Q1 2020 compared to the same period in 2019 (Asiedu 2020). China has in recent years also emerged to be a leading source of funding for investment in Africa's infrastructure. A contraction in China's economy could result in decreased investment funding in Africa. Also, refocusing the Chinese economy away from manufacturing, following COVID-19, suggests that it may require fewer commodity and manufacturing input imports from Africa in future.

Finally, with faster post-COVID-19 recovery occurring in South-East Asia relative to many other parts of the world, China's near-term growth will be more dependent on domestic and regional demand, rather than global demand. A consequent (or coincidental) re-organization of China's value chains towards a regional rather than global focus, post-COVID-19, could reduce China's longer-term dependence for inputs from Africa and thereby harm Africa's export revenues.

\subsection{The effect on structural disruptions in the maritime industry}

COVID-19 can be a catalyst to advance automation, artificial intelligence, and Autonomy while reducing emissions in the maritime sector (Maritime Gateway 2020). PostCOVID-19, the hygiene standards required for handling cargo in the maritime-tolandside supply chain will have to improve. There will also be incentives for more automation in the entire supply chain and for the handling of cargo in a multimodal network. This will not only be a commercial consideration but also a business continuity necessity (Lloyds Register 2020).

Automation and remote operations could facilitate safe and reliable port operations during future pandemics (Valentine 2020). COVID-19 is also expected to accelerate current trends towards digitization in the maritime industry (Twining 2020). COVID-19 will affect regionalization through two main channels. Firstly, uneven economic recovery and speed of re-opening from lockdown states (taking South East Asia as an example), will result in a regional surge of maritime traffic as economies in this area trade more with each other than with other global regions. Secondly, the imperative to restructure global supply chains away from the current overdependence on China will result in geographical strategies with increased segments of supply chains relocated closer to their final consumer markets, which will increase regional movements of maritime traffic - at least in the short-to-medium terms.

With increased risk for the maritime industry because of COVID-19, consolidation may be one of several strategies adopted by industry actors to mitigate risks or to shoreup compressed margins through attendant cost reductions and scale efficiency gains. The pressure of COVID-19 may also provide incentives for opportunistic acquisitions of "cheap assets" as some actors chose to exit the industry under the current difficult conditions. However, if the cost of financing acquisitions increases significantly (given for example that an impending global economic recession does not induce central banks to reduce interest rates below their already low levels), then some consolidations may be deferred until industry conditions improve. 


\subsection{The effect on regulatory pressures}

COVID-19 has largely impacted the capacity of Port State Authorities (PSAs) to conduct on-board inspections of vessels in order to verify whether these regulations are being complied with. Due to the pandemic, it is difficult for PSA's to objectively assess the level of compliance until the public health situation is adequately under control. Regulatory compliance in the maritime industry may also have been sidelined by the crisis of stranded seafarers due to COVID-19.

On April 1, 2020, the UK's Maritime and Coastguard Agency (MCA) announced its suspension of routine port state control inspections, including enforcing MARPOL 2020. It announced that it would only monitor vessels calling at UK ports and inspect vessels if information received suggested that such inspections were warranted. While other Port authorities in Europe and worldwide have not been so explicit, it is anticipated that similar measures will also be adopted by them (Turner 2020).

\subsection{The effect on environmental incidents and pro-environment activism}

On one hand, COVID-19 has induced a reduction in the level of activity within the maritime sector, which has accordingly reduced the quantity of environmentally negative emissions released by the maritime industry. On the other hand, however, the pandemic has led to an increase in the consumption of single-use items (some of which are made of plastic) such as masks, sanitary gloves, and medical equipment. It is anticipated that a significant portion of these items will find their way into water systems and marine areas, thereby increasingly the levels of environmental pollution (ID4D 2020). ${ }^{30}$

COVID-19 is also compelling actors across board, particularly in the MTS, to recognize the imperative of environmental sustainability and resilience, and how these will play a central role in ensuring the long-term sustainability of the sector.

\section{How significant is Africa in the global MTS?}

In 2018, Africa commanded only a minuscule $4 \%$ share of the global container port traffic and was responsible for merely $7 \%$ and $5 \%$ of international maritime trade exports and imports, respectively, measured by tonnage (UNCTAD 2019). The continent's maritime sector has also scored poorly on critical performance indicators such as "line shipping connectivity" and "port turnaround time" (which are proxy measures of efficiency, access to markets, infrastructure endowment, supply side capacity, trade facilitation, and other sustainability parameters) compared with the globally leading maritime economies.

The liner shipping connectivity index (LSCI) is a measure of a country's accessibility to global trade. It is also a measure of a country's connectivity to maritime shipping, maritime competitiveness, and trade facilitation. The higher the index, the easier it is for a country to access the global maritime freight transport system in terms of capacity, transport options, and frequency, and to effectively participate in

\footnotetext{
${ }^{30}$ D4D means Ideas for Development.
} 
international trade. Port turnaround time is an indicator of trade efficiency that determines connectivity and trade costs. This is because every hour of ship time saved in a port helps ports, carriers, and shippers save money on port infrastructure investments, capital expenditures on ships and inventory holding costs of merchandise goods.

Figure 1 below compares LSCI data gathered from 15 key African maritime countries with similar data from 9 globally leading maritime countries between 2006 and q3 2020. The graph on the left shows the LSCI's development for the best performing African countries (based on the index) while the graph on the right shows a similar development for selected countries with (anecdotally) high performing maritime sectors. The data shows that these African countries have an average level of access (and I daresay significance to the global MTS) that is a mere 20\% of the average level of access of the leading maritime countries.

Figure 2 below compares data on port turnaround times from 2018 and 2019 from the same 15 African maritime countries shown above, with similar data from the 9 globally leading maritime countries also shown above. The graph on the left shows that the African countries have an average port turnaround time of about 1.5 days, while the graph on the right shows the leading maritime countries to have an average time of around 0.8 days, which implies an average port turnaround performance that is twice as effective as the African performance. The graph on the right also shows the global or world average port turnaround time to be slightly below 1 day, meaning that African countries on average underperform the global average for this index by approximately $30-50 \%$.

The data presented above shows that in spite of a few exceptional performers such as Morocco and Egypt, Africa's MTS prior to COVID-19 was on a development and performance pathway well below the global average and that of other maritime economies with whom the continent regularly does business. Coupled with its minuscule share of global maritime transport activity, the reality is that the African continent is not a significant player in the international MTS. This is because decades of weak public management, under-investment in maritime infrastructure, an underserved demand for maritime transport and low interconnectivity between land and sea-based logistical networks, have contrived to keep the development and performance of Africa's MTS at a disappointingly low level, relative to other global regions.

It will be premature to conduct an exposition into the impact of the critical trends facing the global MTS (as has been conducted in Section 2 of this paper) on Africa's MTS. This is because the continent's MTS was (pre-COVID-19) at such a low level of development and operational performance that it would be challenging to induce

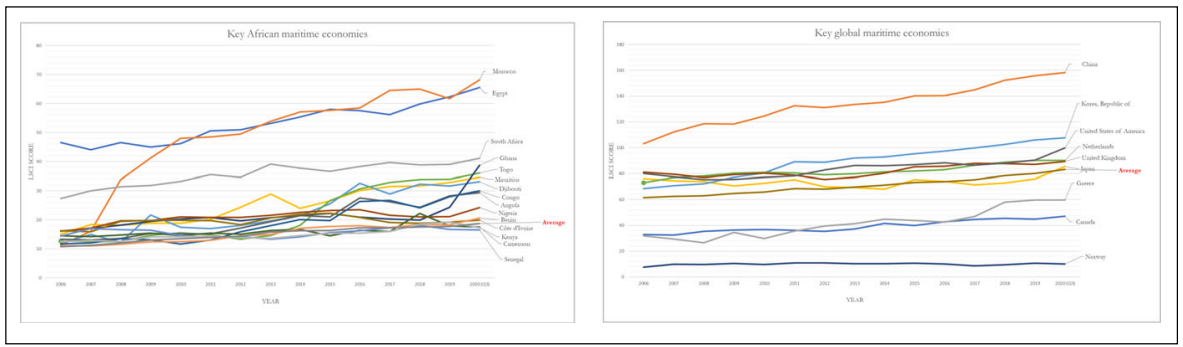

Fig. 1 Line shipping connectivity index (LSCI). Source: unctadstat.unctad.org; own analysis 


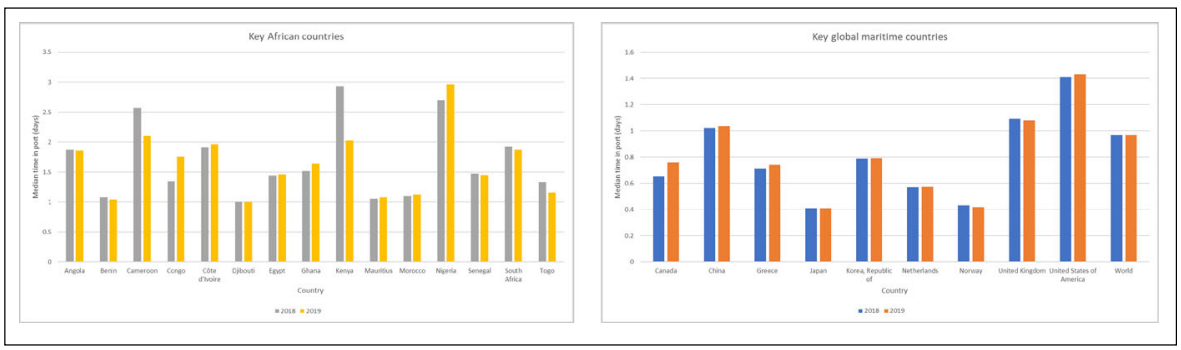

Fig. 2 Port call and performance statistics: time spent in ports. Source: unctadstat.unctad.org; own analysis

meaningful results from such an analysis. Unfortunately, this status-quo ante has merely been exacerbated by the highly disruptive COVID-19 pandemic. Rather than conducting such an analysis, I believe it will be more useful to examine the implications of COVID-19 for Africa's MTS through a normative and prescriptive lens, i.e., one that identifies the logical imperatives for developing the sector and for improving its operational performance as the pandemic recedes.

\section{Imperatives for Africa's MTS in the post-COVID-19 era}

Africa has an enormous potential to grow its footprint in the international MTS in the post-COVID-19 era, more-so as the African Continental Free Trade Area (AfCFTA) becomes active in 2021 (World Bank 2020). ${ }^{31}$ There are however a number of imperatives that the continent's MTS will need to address to put it on an appropriate developmental and operational pathway. We will now briefly examine some of these imperatives.

\subsection{Ports and related services}

As the nexus between the "oceanside" and "landside" elements of the MTS supply chain, ports play an inestimable role in the supply chain. Improvements to port infrastructure, port service, connectivity to other ports and inland freight destinations, or transport hubs will have significant ramifications for Africa's MTS in the postCOVID-19 era. The pandemic has underscored the essential nature of ports to the dayto-day functioning of Africa's economies. This reality needs to be acknowledged by prioritizing the sustainable development of port infrastructure that are compatible with the global trends towards digitization, structural disruption, and environmental and social awareness within the maritime sector. Also relevant are questions about how ports should be governed for optimal effectiveness and sustainable benefit as has been examined by Brooks (2004) and Notteboom and Haralambides (2020).

\footnotetext{
${ }^{31}$ According to World Bank (2020), the AfCFTA agreement will create the largest free trade area in the world measured by the number of countries participating. The pact connects 1.3 billion people across 55 countries with a combined gross domestic product (GDP) valued at US\$3.4 trillion. It has the potential to lift 30 million people out of extreme poverty. As the global economy is in turmoil due to the COVID-19 pandemic, creation of the vast AfCFTA regional market is a major opportunity to help African countries diversify their exports, accelerate growth, and attract foreign direct investment. The agreement will reduce tariffs among member countries and cover policy areas such as trade facilitation and services, as well as regulatory measures such as sanitary standards and technical barriers to trade.
} 


\subsection{Maritime safety and security}

It is essential that Africa's MTS focuses on promoting safety and security within its domain. As defined by European Commission (2006), maritime safety includes the following areas: Safety of the ship, its crew and its passengers, and/or cargo; safety of navigation; prevention of pollution from ships, including the possibility for sanctioning illicit pollution and intervention to limit damage from incidents; and liability and compensation for damages occurred by ships. Maritime security includes the following: border control and immigration; organized crime, smuggling, or trafficking; terrorism; and piracy. In the wake of COVID-19, the importance of personal hygiene, pandemic preparedness, and the wellbeing of seafarers (including their mental health) have risen in significance as maritime safety issues. The question of how to govern the continued provision of maritime safety and security is of essence, as in the absence of these, normal operation of the MTS would be impossible.

\subsection{Developing the significance of shipping}

Shipping development refers to the use of policy, strategic analysis and other measures, both operational and non-operational, to increase the penetration and size of the MTS within Africa. It calls for growing the local demand for shipping services in Africa back to their pre-pandemic levels and beyond, while simultaneously developing the supply side to meet the anticipated expansion in demand. Shipping development also requires the diversification of maritime transport services into new areas, thereby tapping into hitherto unidentified or unsatisfied local demand.

Areas of interest for developing shipping locally include the cabotage or domestic shipping markets, expanding the national ship registry, improving port performance and connectivity - both inland and to other ports, digitalization of shipping and port operations, developing landside (intermodal) transport options from ports, training local personnel with the relevant skillsets for managing the sector's growth, and strengthening the existing governance mechanisms for effective oversight of the sector.

\subsection{Implementing a wholistic strategy for the blue economy}

The blue economy concept seeks to achieve maritime sector related economic growth and social inclusion, alongside the preservation or improvement of human livelihoods, while ensuring the sustainability of such growth through preventing or mitigating environmental degradation. The concept is relevant to states with interests in waters within and beyond their national jurisdictions, and particularly on the African continent where thirty-eight out of fifty-four countries are coastal states. ${ }^{32}$

World Bank and UNDESA (2017) notes that the blue economy encompasses a broad range of economic sectors and related policies that together determine whether

\footnotetext{
32 These include the following: Algeria, Egypt, Libya, Mauritania, Morocco, Sudan, Tunisia, Cameroon, Congo, Equatorial Guinea, Gabon, Democratic Republic of the Congo, Djibouti, Eritrea, Kenya, Madagascar, Somalia, United Republic of Tanzania, Angola, Mauritius, Mozambique, Namibia, South Africa, Benin, Côte d'Ivoire, Gambia (Islamic Republic of the), Ghana, Guinea, Liberia, Nigeria, Senegal, Sierra Leone, Togo, and the African SIDS: Cabo Verde, Comoros, Guinea-Bissau, São Tomé and Príncipe, and Seychelles. Sourced from WESP (2019), Tables C, H and I.
} 
the use of maritime resources is sustainable. Ehlers (2016) expounds on this, specifying that the blue economy spans traditional maritime sectors such as fisheries, tourism, and maritime transport, to newer and emerging sectors such as offshore renewable energy, aquaculture, seabed extraction, marine biotechnology, and bio prospecting. ${ }^{33}$

African Union (2018) notes that the blue economy is the new frontline for Africa's renaissance and one that offers a huge potential for the continent's growth, diversification, and development. This position is further elucidated in AU (2019) which argues that the blue economy integrates into a new approach, the economic exploitation of the resources of oceans, lakes, rivers, and other bodies of water and the conservation of aquatic ecosystems. The blue economy therefore presents a cogent argument for the rational and sustainable use of marine resources (both renewable and non-renewable) and marine habitats in developing coastal states.

The blue economy is best conceived as a long-term strategy that balances the economic, social, and environmental dimensions of maritime and related activities. ${ }^{34}$ Implementing such a strategy requires a defined governance framework for identifying and addressing equity concerns about access-to, development, and distribution of benefits from the maritime sector and related activities. This cannot be achieved without having a coherent approach to managing human activities within (and across) all maritime sectors.

\subsection{Tackling sea blindness}

Sea blindness means the lack of understanding and appreciation by the general public, and by extention African governments, of the benefits provided by the maritime domain. Such blindness, where widespread and untackled as in many African states, undermine arguments for a more diligent public oversight and prudent management of maritime resources. This perhaps lies at the heart of why the utilization and development of Africa's enormous maritime wealth and potential has achieved limited success compared with several less endowed regions around the world. Overcoming sea blindness should be made a policy and operational priority in Africa's maritime states in the post-COVID-19 era. This should also open the door to in-depth discussions about the role and typology of governance frameworks to be adopted for oversight of the maritime industry.

\section{Maritime governance in Africa's MTS in the post-COVID-19 era}

\subsection{The role of maritime governance in Africa's MTS}

Maritime governance is crucial to achieving positive development outcomes in Africa's MTS and is essential for the sector's wellbeing and sustainability in the post-COVID-

\footnotetext{
${ }^{33}$ It should be noted that the blue economy is also relevant to land-locked countries endowed with inland waters that permit the development of blue economy sectors such as fishing, transport, tourism, aquaculture, energy generation, mineral extraction and marine biotechnology, and bio prospecting.

34 Op. cit. World Bank and UN DESA, 2017.
} 
19 era. Burger and Mayer (2003) cite the Commission on Global Governance's (CGG) definition of governance as:

"the sum of the many ways individuals and institutions, public and private, manage their common affairs."

“... a continuing process through which conflicting or diverse interests may be accommodated and cooperative action may be taken."

“... (including) formal institutions and regimes empowered to enforce compliance, as well as informal arrangements that people and institutions either have agreed to or perceive to be in their interest." 35

Henisz et al. (2019) also define governance as the internal system of practices, controls, and procedures that a company (organization or state) adopts in order to govern itself, make effective decisions, comply with the law, and meet the needs of external stakeholders.

The World Development Report (2017) observes that while governance is the process of designing and implementing policy, inequities in this process can result in a persistent cycle whereby effective policies are not adopted or are unsuccessfully implemented. It further identifies that: "policy making does not occur in a vacuum. Rather, it takes place in complex political and social settings in which individuals and groups with unequal power interact within changing rules as they pursue conflicting interests," and that: "who participates in the decision-making process fundamentally matters for the selection and implementation of policies - and consequently, their impact on development outcomes."

The role of maritime governance in maritime policy development and implementation is essentially threefold: (1) to facilitate the inclusion of all stakeholders who should be party to the process because of their interest-in or exposure-to the final outcomes; (2) to ensure that the process is equitable and sufficiently transparent, i.e., that all parties have the capacity to influence outcomes and that no party can unduly influence or capture the process; and (3) to provide appropriate and adequate incentives for stakeholders' participation and (dis-incentives) to discourage those who wish to take advantage of the process.

In the context of Africa's post-COVID-19 MTS, facilitating the inclusion of all relevant stakeholders calls for viewing the entire MTS value chain as integrated and interconnected and thereby constituting a community that should be consulted when decisions are to be made affecting any part of the value chain. For example, decisions on policies affecting a sea port should not be restricted to stakeholders with a direct or physical connection to the port infrastructure, but should include other stakeholders in the MTS value chain from shipping companies up to inland freight and logistics hubs. Defining the entire value chain as the appropriate reference community for decisions affecting portions of the MTS acknowledges the reality of an increasingly integrated and interconnected value chain.

Having an equitable and transparent process for policy development and implementation in the MTS is essential. It will preserve the process from being unduly dominated, hijacked, or captured by powerful interests in the value chain. For example, international shipping lines with access to globally sourced financial resources, may be able to drown-out the interests or viewpoints of less endowed local communities or

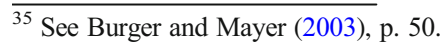


civil-society organizations when the policy making and implementation process is opaque. Similarly, lobby groups with privileged "backroom" access to the regulator or oversight ministry, would be better positioned to influence the MTS' developmental outcomes to their own benefit and to the possible detriment of weaker stakeholders.

As is often the case in the shared utilization of a public good with open or unrestricted access, there is a tendency for atomistic and rational actors to free ride on the costly commitments of other stakeholders. This means that in a situation wherein stakeholders in the MTS value chain choose to act co-operatively and coordinate their actions via the collective implementation of defined policies, an individual actor may opportunistically seek to maximize its private benefit by refusing to participate in the process or to make any costly commitments to implementing policies. Where such a situation exists, it means that the free-rider's incentives to maximize its private benefit are not aligned with the incentives it faces to act to maximize the public or social benefit. Hence, the propensity to free-ride or act opportunistically. A role of maritime governance in the MTS is to provide adequate incentives (or dis-incentives) that eliminate such free-rider behaviors.

\subsection{A generic framework for maritime governance in Africa's MTS}

The framework for maritime governance that is presented in this section is adapted from a framework presented in the World Development Report (2017). ${ }^{36}$ This framework is comprised of three unique and interconnected elements which are the following: (1) the policy arena; (2) rules; and (3) development outcomes.

Figure 3 below presents the interconnectedness between the three elements of the framework. Observe that participants or stakeholders interact within a policy arena that is both defined and sustained through respect for a system of rules, to realize stated development outcomes that support the sustainable existence of the MTS.

Flexibility in the framework is provided by allowing the participants, subject to adhering to approved mechanisms or processes, to change or adjust the rules in order to evolve the framework into being better suited to satisfy a dynamic array of developmental outcomes. Legitimacy or voluntary acceptance and co-operation with the framework will be strengthened when power asymmetries are not exploited/are effectively mitigated. Inclusive participation by relevant stakeholders, notably those directly affected by policies emanating from the framework, is also essential for legitimacy.

\subsubsection{The policy arena}

As with any real-world sector, the MTS consists of interactions between multiple stakeholders - including individuals, groups, and sovereign states with their delegated

\footnotetext{
${ }^{36}$ Permission to adapt this framework is provided under the Creative Commons Attribution 3.0 IGO license (CC BY 3.0 IGO) http://creativecommons.org /licenses/by/3.0/igo. This license permits copying, distribution, transmission, and adaptation of the work subject to attribution and an included disclaimer. Source: Adapted from the World Development Report (2017). Reproduced under Creative Commons Attribution license. http:// creativecommons.org/licenses/by/3.0/igo. Disclaimer: This is an adaptation of an original work by The World Bank. Views and opinions expressed in the adaptation are the sole responsibility of the author or authors of the adaptation and are not endorsed by the World Bank.
} 


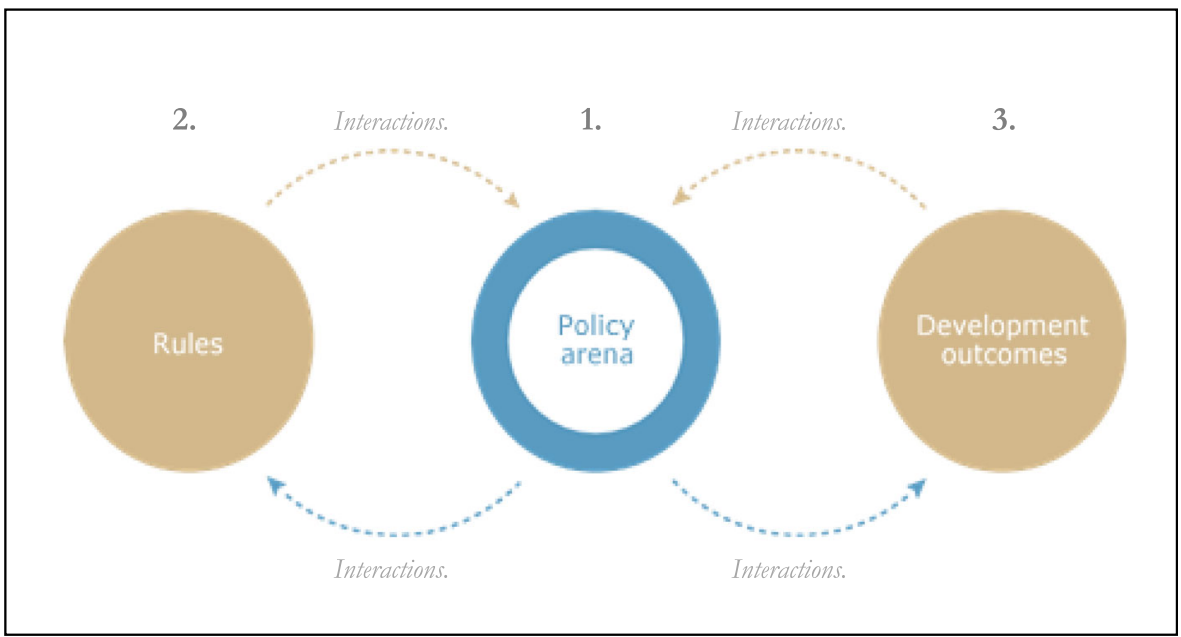

Fig. 3 A framework for maritime governance

entities. These stakeholders often pursue conflicting interests that underlie their presence and activities in the sector and interact with each other in multiple and complex ways.

The space within which stakeholder interactions occur is defined as the policy arena. The policy arena may be further split into formal and informal arenas. For the MTS, the formal policy arena would naturally include participants in the sector's value chain, regulators, government agencies, oversight ministries, parliament, law courts and arbitration panels, non-governmental organizations, and any other formally recognized stakeholders (which may or may not include local communities' representatives). Each participant in the formal policy arena will have a statutory or legal basis validating its participation in the arena.

The informal policy arena for the MTS on the other hand includes personal and often private networks, most of which are difficult to document owing to their non-formality, i.e., not requiring statutory validation and their "private, non-transparent or restricted access" nature. It is crucial to note that the relative significance and influence of the formal vs. informal policy arenas on decision making and implementation can be difficult to quantify and can be expected to vary from place-to-place.

\subsubsection{Rules}

Stakeholders interact not only to develop and implement policy, but also to change the rules under which their interaction occurs. We consider these rules in four different categories: (1) Rules as the outcomes of ratified international maritime agreements and conventions. (2) Rules as maritime policies, introduced at the national level with legal or statutory backing. (3) Rules as statutorily backed mandates or charters that define the organizational form, 
powers, and formal independence of institutions within the MTS. (4) Rules as mechanisms designed to oversee and thereby legitimize changes to the rules. ${ }^{37}$

The cornerstone of international maritime governance is the UN Convention on the Law of the Sea of 1982 (UNCLOS). ${ }^{38}$ Goettsche-Wanli (2018) describes UNCLOS as the Constitution for the oceans. This is because the convention provides the foundational legal framework underpinning the global maritime system. The UNCLOS' principles and implementation agreements constitute binding international law for all countries and are therefore fundamental when defining the rules for maritime governance at the national and regional levels. Rules arising from other bilateral and multilateral treaties, agreements, and conventions, where binding, also fall into the first category of rules.

The second category of rules are those emanating from national maritime policies or strategic plans with statutory backing. One example is the Seychellois Blue Economy Strategic Framework and Roadmap that was approved by the Government of Seychelles on 31st January 2018 (Republic of Seychelles 2018). ${ }^{39}$ Another example (although not from Africa) is the Norwegian Barents Sea Integrated Management Plan (BSMP) that was adopted by the Norwegian Parliament in $2006 .{ }^{40}$

The third category of rules refers to the mandates, charters, or other forms of statutory validations that define and concretize the capacity (i.e., power and ability) of maritime institutions to convene the relevant actors and to effectively exercise power towards actualizing their stated objectives. An example of this is the Mombasa Port and Northern Corridor Community Charter (2020) 2018-2024. ${ }^{41}$

\footnotetext{
${ }^{37}$ The World Development Report (2017) framework considers rules on three different levels: (Adetuyi and Williams 2020) rules as policies; (Union 2018) rules as organizational forms; and (Union 2019) rules as mechanisms to change the rules themselves.

${ }^{38}$ The 1982 United Nations Convention on the Law of the Sea (UNCLOS), together with its implementing agreements - the 1994 Agreement relating to the implementation of Part XI of UNCLOS and the 1995 United Nations Fish Stocks Agreement - sets out the legal framework within which all activities in the oceans and seas must be carried out and is of strategic importance as the basis for national, regional, and global action and co-operation in the marine sector. This includes the conservation and sustainable use of all areas of the oceans and their resources.

${ }^{39}$ The Seychellois Blue Economy Roadmap is an integrated approach to ocean based sustainable development that integrates economy, environment and society in alignment with: the Sustainable Development Agenda 2030; Aichi Target 11 of the Convention on Biological Diversity (CBD); and the Paris Agreement on Climate Change (2015). The roadmap articulates Seychelles "Blue Economy Brand" launches a maritime spatial planning initiative, issues an innovative sovereign blue bond to finance fisheries projects, and puts forward a prioritized agenda for action and investment to 2030. Source: Republic of Seychelles. Seychelles Blue Economy: Strategic Policy Framework and Roadmap - Charting the future (2018-2030).

${ }^{40}$ The Norwegian BSMP is based on Integrated Ocean Management (IOM) and was introduced to reduce conflicts between the petroleum and traditional fishing industries in the Barents Sea. Source: Hoel and Olsen (2012).

${ }^{41}$ The Charter was established in 2014 to realize the full trade facilitation potential of the Mombasa port and Northern corridor community. Signed by both public and private institutions, it represents the culmination of extensive consultations among all port stakeholders that yielded a framework aimed at achieving seamless transport along the port and corridor. The Charter's formation was spearheaded by Trademark East Africa (TMEA) and the Kenya Ports Authority (KPA) both of whom brought together key stakeholders in the public and private sector for its development. It is supported by the Government of Kenya through the Ministry of Transport, Infrastructure, Housing, Urban Development and Public Works. The Charter has four main objectives: (a) to establish a permanent framework of collaboration that binds the port community together to specific actions, collective obligations, targets, and timelines; (b) to complement the individual institutional service charters in addressing the challenges that act as barriers to trade facilitation along the port and corridor; (c) to introduce, educate, and publicize to all stakeholders the industry customs and practices embraced by the port community so as to rightfully influence all persons in the region participating in international trade; and (d) to develop and implement a self-monitoring and evaluation mechanism for collective community obligations. Source: The Mombasa Port \& Northern Corridor Community Charter (2020) 2018-2024.
} 
The fourth category of rules concerns those mechanisms/processes that oversee and give legitimacy to changes in the rules adopted by the maritime governance framework. This category of rules is likely to vary the most in its form, depending on the norms and historical experiences at a given location. To have legitimacy, without reverting to the coercive power of the state, existing or new rules should elicit the confidence of a majority of stakeholders.

\subsubsection{Developmental outcomes}

The primary developmental outcome from maritime governance is respect for a system of norms or regulations that guarantee a minimal level of security essential for meaningful maritime activity to subsist. Hence, maritime governance must necessarily result in improvements to maritime security. Vrancken (2018) notes that it was a deteriorating maritime security situation that spurred African states into taking steps towards developing an integrated approach to governance in the African maritime domain. $^{42}$

Maritime governance is also essential to realizing the 2030 Agenda for a sustainable MTS in Africa. This refers most notably to Sustainable Development Goal (SDG) 14 to: "Conserve and sustainably use the oceans, seas and marine resources for sustainable development." Other developmental outcomes include facilitating the realization of Africa's trade potential; providing a relevant policy and regulatory framework for the development of Africa's MTS and blue economy; increasing compliance with maritime regulations through effective policy implementation and enforcement; and strengthening the norms of transparency and accountability in the MTS.

Table 1 below provides a summary of the main components of the maritime governance framework.

\subsection{Alternative frameworks for maritime governance in Africa's MTS}

A central objective of this paper is to identify relevant governance frameworks for Africa's MTS, and to examine how these frameworks may (or should) be affected in the wake of the COVID-19 pandemic. An accepted typology for distinguishing between alternative governance frameworks is to define the alternatives in terms of the extent of traditional government (or the state's) involvement.

Cashore (2002) distinguishes between alternative frameworks by locating the governing authority along a continuum having the sovereign state, public sector or traditional government at one extreme, and non-state or market-based actors at the other extreme. He identifies three alternative frameworks as the following: traditional government or public governance, shared private/public governance, and non-state marketdriven (NSMD) governance. Haufler (2003) views governance frameworks from the

\footnotetext{
$\overline{42}$ The four main steps outlined by Vrancken (2018) were the following: the adoption by the Conference of ministers responsible for maritime transport in 2009, of the Durban Resolution on Maritime Safety, Maritime Security and Protection of the Marine Environment in Africa; the production in 2010, of a discussion paper on maritime development in Africa; as well as the adoption by the AU Assembly of the 2050 Africa's Integrated Maritime Strategy ("the AIMS") in 2014; and in October 2016, the Lomé Charter on Maritime Security and Safety and Development in Africa (the Lomé Charter'), a formal treaty which will bind States Parties once it comes into effect.
} 
perspective of regulatory mechanisms, with regulation loosely defined as the "limits imposed on the behavior of particular actors, contained in rules and standards that are not voluntary." She identifies four alternative regulatory/governance frameworks as follows: traditional regulation, co- regulation, industry self-regulation, and multistakeholder regulation.

There are parallels between Haufler and Cashore's alternative frameworks. Haufler's traditional regulation mechanism corresponds with Cashore's traditional government framework. In both cases, policy is developed, promulgated, and enforced by the state itself, or by the public sector on behalf of the state. Haufler's co-regulation mechanism corresponds to Cashore's shared governance framework. Here, the state shares/ delegates its policy making authority with/to private actors, but the power to enforce such policy remains with the state. Haufler's industry self-regulation mechanism is in principle similar - although not exactly equivalent - to Cashore's non-state governance framework. Here, non-state actors (i.e., the private sector) have the authority to develop and implement policies, including technical standards and best practices. The application of these policies is however voluntary and hence not the prerogative of the state ${ }^{43}$.

Uniquely, policies produced under Haufler's multi-stakeholder regulation mechanism are the collective responsibility of the state, private, and civil-society sectors. ${ }^{44}$ Burger and Mayer (2003) refer to governance frameworks involving these three actor types as creating a "multifaceted architecture of co-governance." 45 They identify cogovernance frameworks (i.e., in which all three actor types coordinate and harmonize their involvement in governance) to be of particular interest to the governance of value creation chains involving numerous actors in the physical transformation of raw materials into end products that are delivered to final consumers.

\subsection{Identifying an appropriate maritime governance framework for Africa's MTS after COVID-19}

A major challenge, for researchers and practitioners alike of maritime governance in Africa's MTS, is to identify an appropriate governance framework for deployment in the African context. There is often a costly misconception that governance frameworks, already deployed with some success in better developed maritime economies - for example in OECD countries ${ }^{46}$ - may be readily rolled-out in African contexts with similar expectations for success. This is logically not the case.

\footnotetext{
$\overline{43}$ Cashore's NSMD governance framework is a variant of the non-state governance framework in which market mechanisms determine what policies are implemented. Compliance with defined policies is required to be verifiable with the responsibility for imposing sanctions for non-compliance being devolved to the market. The state is permitted to participate in the framework but merely as one of several actors.

${ }^{44}$ Haufler differentiates multi-stakeholder regulation from the other three types of regulation by the influential role played by non-profit or civil-society groups in the multi-stakeholder framework (see p. 239). The definition of civil-society groups may, within this framework, also be extended to include local community or citizen action groups that legitimately represent and advocate the interests of the relevant local communities. 45 See Burger and Mayer (2003) p. 53.

46 The Organization for Economic Co-operation and Development (OECD) is an international organization linking the better developed, wealthier, and predominantly Western hemisphere economies. Current member countries are the following: Australia, Austria, Belgium, Canada, Chile, Colombia, Czech Republic, Denmark, Estonia, Finland, France, Germany, Greece, Hungary, Iceland, Ireland, Israel, Italy, Japan, Korea, Latvia, Lithuania, Luxembourg, Mexico, Netherlands, New Zealand, Norway, Poland, Portugal, Slovak Republic, Slovenia, Spain, Sweden, Switzerland, Turkey, UK, USA. Source: oecd.org.
} 
Table 1 Components of the maritime governance framework

\# Participants in Sources of rules Developmental outcomes
the policy arena

1 Actors in the MTS UNCLOS and related agreements value chain

2 Regulators, government agencies, and oversight ministries

3 Parliament, law courts, and arbitration panels

4 Civil society organizations

5 Other formally recognized stakeholders

6 Informal personal and private networks
Bilateral and multilateral treaties, conventions, and agreements

National maritime policies or strategic plans with statutory backing

Mandates, charters or other forms of statutory validations underlying maritime institutions

Statutory mechanisms for changing maritime governance rules

Non-statutory or informal mechanisms for changing maritime governance rules
An MTS that facilitates the realization of Africa's trade potential

Providing a framework that promotes maritime security

Supporting the realization of the 2030 Agenda for a sustainable MTS

Providing a relevant policy and regulatory framework for the MTS and blue economy

Increasing compliance with maritime regulations through effective policy implementation and enforcement

Strengthening the norms of transparency and accountability in Africa's MTS

As has been argued in an earlier section of this paper ${ }^{47}$, Africa's MTS was preCOVID-19 (largely) at such a low level of development and operational performance that understanding its responses to global MTS trends ${ }^{48}$ would require a distinct analysis to that conducted on better developed maritime economies. The COVID-19 pandemic has merely exacerbated this disparity.

The global, pre-COVID-19 trend towards increasing integration (horizontal and vertical) in maritime supply chains, and the expansion of such chains into inland distribution networks, meant that multinational businesses and private sector interests were poised to become more dominant in the global MTS. If the current contractions in global maritime activity - induced by the COVID-19 pandemic - persist in the postpandemic era, then a fresh wave of cost-trimming rationalizations in the MTS is to be expected. This would imply further integration/consolidations in the global MTS, with even greater influence over the sector resultantly residing on the private sector side.

The erosion of the state's capacity for effective governance has been adduced to the impacts of globalization and privatization. Both impacts have resulted in the "deterritorialization of financial and information flows, and of value creation chains. [Hence] transnational enterprises are increasingly moving beyond the reach of state control, which constrains states' scope for action to effectively govern such enterprises" (Burger and Mayer 2003, p. 51). The internationalization of value chains and the development of an integrated global market appears to have outstripped the governance capacities of states and multilateral oversight systems (Haufler 2003, p. 241$)^{49}$.

\footnotetext{
${ }^{47}$ See section 4.

${ }^{48}$ See Section 2 and Section 3.

${ }^{49}$ Although some level of value chain re-shoring is expected in the wake of COVID-19, this will most likely not reverse the globalization trend.
} 
Prominent among the impacts of COVID-19 in Africa's MTS has been a severe reduction of maritime activity levels, decreased public sector revenues, and the constriction of port state authorities' ability to physically inspect incoming vessels. These impediments have further constrained the already limited capacity of Africa's maritime authorities to oversee the activities of an increasingly international, integrated, and dominant private sector (see Turner 2020, and Prins 2020).

Consequently, the application in Africa's MTS of maritime governance frameworks based on Haufler's traditional regulation, co-regulation, and industry self-regulation models would be either debatable or simply inappropriate, in the post-COVID-19 reality. This is because a weakened state due to COVID-19 would be less capable (without providing adequate remedies) of performing its full oversight responsibilities under the traditional regulation framework. Haufler's co-regulation model, postCOVID-19, would likewise entail collaboration between a weaker state and a presumably stronger (or strenghtened) private sector. Such a change in the regulatory power dynamic could result in policies and implementations that are skewed in favor of private sector interests, thereby resulting in a failure of governance.

Similarly, Haufler's industry self-regulation model would be on shaky ground postCOVID-19. This is because a stronger, more integrated, and international private sector, with even smaller prospects (relative to the pre-pandemic situation) for being challenged, corrected or coerced by the state to do the right thing, would presumably act in its own best interest, which may be to the detriment of the societal best interest.

Inferably, Haufler's multi-stakeholder regulation model would provide the most appropriate governance framework for Africa's MTS in the post-COVID-19 era. This is because introducing (and formalizing) the role of civil-society actors in the governance framework could serve to support and strengthen the state's weakened oversight capacity vis-à-vis the private sector, thereby countering the increased power of private interests. An example of a multi-stakeholder governance framework in Africa's MTS is the Mombasa Port Community Charter, which has been earlier referenced in this paper.

A unique feature of the COVID-19 pandemic is that it has highlighted the vulnerability of our current human civilization (i.e., the organization of political institutions, modes of doing business, socializing, etc., at the local, national, and international levels) to a severe, unexpected, and prolonged shock. Africa has been relatively fortunate in that it has fared much better than expected under the pandemic. A less fortunate outcome for Africa from COVID-19 (or some other catastrophic event in future) could have left African states paralyzed and unable to adequately fulfill their governance obligations.

Such a crisis could readily result in changes to the international political economy that would result in the reversion of political governance to a "neo-medievalist" status quo, as argued by Kobrin (1999) ${ }^{50}$. The distinguishing feature of Kobrin's neomedievalist metaphor is that sovereign states lose their capacity or capability to effectively govern their domains (in this case the maritime one). Simply stated, this

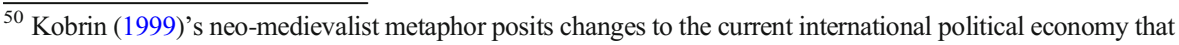
would impact the status quo definition, structure, or powers of sovereign states, arising from the Peace Treaty of Westphalia, 1648, and returning them to their pre-Westphalian or medieval situations. The Peace Treaty of Westphalia, 1648, transformed the medieval European landscape with multiple overlapping territories and jurisdictions to one, in which nation states emerged with unique geographical jurisdictions, and boundaries, and with unchallengeable political authority within their boundaries.
} 
would imply the breakdown or suspension of the nation state's governance ability and the replacement of national governance with an internationally supervised or crossborder governance framework, or simply the absence of any legitimate governance framework.

In the neo-medievalist reality (which is admittedly extreme), a flexible, multi-tiered, and multi-stakeholder approach to maritime governance would allow ultra-weak African states to more flexibly adjust the co-governance relationship between the state, private sector, and civil society, in response to the changing power dynamic within the maritime sector. In such an extreme situation, the multi-stakeholder model would presumably be the most resilient alternative for maritime governance.

\section{Conclusion}

We have in this paper examined the impact of the COVID-19 pandemic on the MTS, at the global level and in the African context. The global analysis indicates that the pandemic may have induced a global economic recession that has further reduced the level of trade between the USA and China, thereby compounding the negative effects of ongoing Sino-American trade tensions on the MTS.

This notwithstanding, Asia's rapid recovery from the pandemic-induced economic recession presages a strengthening of intra-Asian trade with increased regional demand for maritime transport. In order parts of the world, the pandemic will strengthen trends towards regionalization as different global centers of economic activity move to restructure their supply chains away from current perceptions of being overdependent on China.

Such restructuring will follow geographically focused strategies that will see the relocation/reshoring of supply chain segments closer to the end-user markets. Longdistance maritime transport may suffer as a result, but the impact on global maritime transport will depend on whether shorter distance/regional transportation within the relocated supply chains relies more/less on maritime rather than intermodal transport solutions.

Consolidation in global supply chains may be one of several strategies adopted by MTS actors to mitigate heightened risks or to shore-up compressed margins through cost reductions and scale efficiency gains. Incentives for opportunistic acquisitions of "cheap assets," as some actors opt to exit the MTS under the current difficult conditions, may also contribute to higher consolidation activity than otherwise. Such activity may however be reliant on the prevalent cost of financing acquisitions. Were these costs to increase, perhaps because over-inflation averse central banks hold back from further reducing interest rates below their low current levels, then some consolidations may be deferred until the economic environment adequately improves.

The pandemic has also worsened the already severe impact of US trade sanctions imposed on the Islamic Republic of Iran. What was previously (largely) an economic crisis has now escalated into combined healthcare and economic crises. It is however not clear the extent to which the Iranian state, weakened by both crises, may be less/ more of a geopolitical gadfly to maritime activity in the strategically important strait of Hormuz. It is however worthy of note that a destabilized and impoverished Iran, faced with the risk of regime change, may be a more volatile and less predictable actor on the foreign policy front. COVID-19 has similarly compounded the negative impacts of continued US sanctions on the export of Venezuela's crude oil. Unlike the case of Iran, 
however, it is doubtful whether a destabilized and weakened Venezuela will be able to create/sustain geopolitical tensions that may threaten maritime transport in the Latin American region, for example in the Caribbean Sea.

COVID 19 is expected to accelerate current trends towards digitization in the maritime industry. It may also serve to propel the adoption of new technologies related to automation, artificial intelligence, and autonomous vessels in the maritime sector. These new technologies will contribute towards reducing harmful emissions. The hygiene standard in the MTS is expected to improve globally. While the implementation of some international environment regulations like MARPOL 2020 may have been delayed by the pandemic, it has compelled actors across board, particularly in the MTS, to recognize the importance of environmental sustainability and resilience within the maritime sector.

In the African context, the low level of development and operational performance of Africa's MTS makes it challenging to meaningfully analyze the impacts of the pandemic on globally recognizable maritime industry trends. The focus of Africa's MTS in the post-COVID-19 era should therefore be on how to develop sustainably, and how to achieve better operational performance, in alignment with the United Nations' 2030 Agenda. Notably, Sustainable Development Goal (SDG) 14 to "Conserve and sustainably use the oceans, seas and marine resources."

The imperatives for Africa's MTS in the wake of COVID-19 must include the following: developing its ports and related services; improving maritime safety and security; developing shipping as a viable means of local and regional transportation; implementing an inclusive blue economy strategy; and tackling sea blindness. In addition, Africa must improve its maritime governance to ensure that the desired developmental outcomes for the MTS are successfully realized. A multi-stakeholder approach would identifiably provide the most appropriate maritime governance framework for Africa's MTS in the post-COVID-19 era. The multi-stakeholder framework would promote collaborative co-governance between the state, private sector interests, and civil-society organizations.

Africa has arguably been fortunate to have avoided the worst-case scenarios of the COVID-19 pandemic. It will however be utterly imprudent if Africa's MTS does not adequately prepare itself against the realization of a future shock that could rival COVID-19 in its global scale and devastative potential. Adopting a multi-stakeholder governance framework would equip Africa's MTS with a resilient form of maritime governance that would be flexible and immensely useful in the event of a similar or more severe systemic shock than the COVID-19 pandemic. Further research is however needed to identify how the multi-stakeholder governance framework should be adapted and deployed to fit different contexts in Africa's MTS.

\section{Code availability Not applicable.}

\section{Funding This study is self-funded.}

Data availability Figures 1 and 2 are constructed from publicly accessible data on unctadstat.unctad.org. Figure 3 is adapted from the World Development Report (2017) and reproduced under Creative Commons Attribution license. http://creativecommons.org/licenses/by/3.0/igo. 


\section{Declarations}

Ethics approval Not applicable.

Consent to participate Not applicable.

Consent for publication Not applicable.

Conflict of interest The authors declare no competing interests.

\section{References}

Adetuyi A. and Williams, N. 2020. COVID-19: Covid-19: Understanding contractural issues in africa's maritime industry. Published by Brooks \& Knights on ICLG.com on 20. April 2020. https://iclg.com/ briefing/11497-covid-19-understanding-contractural-issues-in-africa-s-maritime-industry\#_ftn2. Browsed 17.08.20, 20.20.

African Union (2018). Consultancy Services for the Development of an African Union Blue Economy Strategy, Reference No.: AUC/DTI/C/110, https://au.int/en/bids/20181123/consultancy-servicesdevelopment-african-union-blue-economy-strategy. Browsed 28.11.19, 15.30.

African Union (2019). Inter-African Bureau for Animal Resources, Blueprint for Africa Blue Economy Strategy (Popular version)

Alix Partners (2019). 2019 Global Container Shipping Outlook. https://www.alixpartners.com/insightsimpact/insights/2019-global-container-shipping-outlook/. Browsed 10/10/2020. 23.04.

Alix Partners (2020). 2020 Global Container Shipping Outlook. https://www.alixpartners.com/insightsimpact/insights/container-shipping-report-2020/. Browsed 12/10/2020. 14.13.

Asiedu KG (2020) Trade between China and Africa dropped 14\% in the first quarter and could get worse. April 23, 2020 https:/qz.com/africa/1844049/trade-between-china-and-africa-dropped-14-percent-in-thefirst-quarter/. Accessed 19 Oct 2020.

Baldwin, R. and Tomiura, E. (2020). 'Thinking ahead about the trade impact of COVID-19' in 'Economics in the Time of COVID-19'. Baldwin, R. and Weder di Mauro, B. (eds.), Centre for Economic Policy Research (CEPR) 2020.

Baldwin, R. and Weder di Mauro, B. (2020). 'Introduction' in 'Economics in the Time of COVID-19'. Baldwin, R. and Weder di Mauro, B. (eds.), Centre for Economic Policy Research (CEPR) 2020.

BBC.com (2019). Brazil oil spill: Greek-flagged tanker believed to be source. Published 2 November 2019. https://www.bbc.com/news/world-latin-america-50268527. Browsed 13/10/2020. 12.46

BBC.com (2020a). Venezuela's National Assembly investigates oil spill. Published 13 August 2020. https:// www.bbc.com/news/world-latin-america-53767424. Browsed 13/10/2020. 12.37.

BBC.com (2020b). Why the Mauritius oil spill is so serious. Published 12 August 2020. https://www.bbc. com/news/world-africa-53754751. Browsed 13/10/2020. 12.40.

BBC.com (2020c). Russian Arctic oil spill pollutes big lake near Norilsk. Published 9 June 2020. https://www. bbc.com/news/world-europe-52977740. Browsed 13/10/2020. 12.43.

Berti, A. 2020. The impact of Covid-19 on global shipping: part 1, system shock. Ship-Technology.com. Published online 2. April 2020. https://www.ship-technology.com/features/impact-of-covid-19-onshipping/. Browsed 16.08.20, 14.47.

Brooks MR (2004) The governance structure of ports. Rev Netw Econ 3(2):168-183. January 2004. https:// doi.org/10.2202/1446-9022.1049.

Burger, D. and Mayer, C. (2003). Making sustainable development a reality: the role of social and ecological standards. Chapter 3 - Challenges for Sustainable Development. Published by: Deutsche Gesellschaft für Technische Zusammenarbeit (GTZ) GmbH.

Cashore, B. (2002). Legitimacy and the privatization of environmental governance: how Non-State MarketDriven (NSMD) Governance Systems Gain Rule-Making Authority. Governance: An International Journal of Policy, Administration, and Institutions, Vol. 15, No. 4, October 2002 (pp. 503-529).

Christie, R. (2020). Opinion piece - How will COVID-19 impact Brexit? The collision of two giant policy imperatives. May 19. https://www.bruegel.org/2020/05/how-will-covid-19-impact-brexit-the-collision-of- 
two-giant-policy-imperatives/2020/05/how-will-covid-19-impact-brexit-the-collision-of-two-giantpolicy-imperatives/. B:14/10/20. 14.30.

Devermont, J. and Catherine Chiang (2019). Innocent bystanders: why the U.S.-China trade war hurts African economies. April 9 https://www.csis.org/analysis/innocent-bystanders-why-us-china-trade-war-hurtsafrican-economies\#: :text=Sub\%2DSaharan\%20African\%20countries\%20are,the $\% 20$ U.S.\%2DChina\% 20 trade $\% 20$ war.\&text=African $\% 20$ Development $\% 20$ Bank $\% 20$ experts $\% 20 \mathrm{warn}$, for $\% 20$ oil $\%$ 20exporters\%20by\%202021. B:19/10/20. 11.19.

Djavad Salehi-Isfahani (2020) Op-Ed. Iran: The double jeopardy of sanctions and COVID-19. Wednesday, September 23, 2020. https://www.brookings.edu/opinions/iran-the-double-jeopardy-of-sanctions-andcovid-19/. B:14/10/20. 15.20.

Dollar, D. and Anna Newby (2020). Podcast transcript - How is COVID-19 affecting US trade? Monday, August 10 https://www.brookings.edu/podcast-episode/how-is-covid-19-affecting-us-trade/ B:14/10/20. 13.57 .

Ehlers P (2016) Blue growth and ocean governance- how to balance the use and the protection of the seas. WMU Journal of Maritime Affairs, October 2016 15(2):187-203

European Commission (2006) Background Paper No. 6 On Maritime Safety and Security - Supplement to the the EC Green Paper on Maritime Policy [COM(2006) 275]. https://ec.europa.eu/transparency/regdoc/rep/ 2/2006/EN/2-2006-689-EN-1-7.Pdf. Accessed 23 Nov 2020.

Goettsche-Wanli, G. (2018). Chapter 1: The role of the United Nations, including its Secretariat in Global Ocean Governance, in Part I Assessing the UN Institutional Structure for Global Ocean Governance: The UN's Role in Global Ocean Governance. From: The IMLI Treatise on Global Ocean Governance: Vol. I.

Haufler, V. (2003): New Forms of governance: certification regimes as social regulations of the global market. In: Social and Political Dimensions of Forest Certification. Meidinger et al. (eds): 237-248. www. forstbuch.de.

Henisz, W., Koller, T., and Nuttall, R. 2019. Five ways that ESG creates value. Mckinsey Quarterly. November 2019.

Hoel, A.H and Olsen E., 2012. Integrated ocean management as a strategy to meet rapid climate change: the Norwegian case. AMBIO 41:85-95· February 2012.

Humphreys RM, Dumitrescu A, Biju NO, Lam YY (2020) COVID-19 and the maritime and logistics sector in Africa. Transport Global Practice, World Bank Group

ID4D (2020) Plastic: An environmental challenge made worse by Covid-19. 06 July, 2020. https:// ideas4development.org/en/plastic-environmental-challenge-covid-19/. Accessed 16 Oct 2020.

International Maritime Organization (IMO). (2020). Statement by the IMO Secretary-General Mr. Kitack Lim. Coronavirus (COVID 19) - Communication from the Secretary-General regarding the crew change crisis. 4 september 2020. http://www.imo.org/en/MediaCentre/PressBriefings/Pages/26-Allow-crew-changes. aspx. Browsed 09/09/2020. 14.36.

King, M. (2019). Digital initiative can 'change course' of container shipping. Lloyds Loading List. Thursday, 18 April 2019. https://www.lloydsloadinglist.com/freight-directory/news/Digital-initiative-can-changecourse-of-container-shipping/74166.htm\#.X31_QWgzZPY. Browsed 08/10/2020. 14.59.

Kobrin SJ (1999) Back to the future: neo-medievalism and the postmodern digital world economy. Chapter 6. In: Prakash A, Hart J (eds) The Globalization and Governance. Routledge, London and New York 1999

Lloyds Register (2020) COVID-19: Maritime's opportunity to advance Automation, AI and Autonomy. 03 Aug, 2020. https://www.lr.org/en/insights/articles/maritime-opportunity-to-advance-automation-ai-andautonomy/. Accessed 16 Oct 2020.

Lloyds Shipping List (2019). Maersk to switch focus to inland logistics. Published on Monday, 01 July 2019 https:/www.lloydsloadinglist.com/freight-directory/news/Maersk-to-switch-focus-to-inland-logistics/ 74563.htm\#.X4Q222gzZPY. Browsed 12/10/2020. 13.02.

March, D.; Metcalfe, K; Tintoré, J.; Godley, B.J. 2020. Tracking the global reduction of marine traffic during the COVID-19 pandemic. in review - Nature Research. https:/www.researchsquare.com/article/rs-47243/ v1. Browsed 04.09.20. 15.01.

Maritime Gateway (2020) Webinar transcript on the impact of Covid-19 on shipping and logistics. http:// www.maritimegateway.com/impact-covid-19-shipping-logistics/. Accessed 15 Oct 2020.

McKibbin, W. and Fernando, R. (2020). 'The economic impact of COVID-19' in 'economics in the time of COVID-19'. Baldwin, R. and Weder di Mauro, B. (eds.), Centre for Economic Policy Research (CEPR) 2020.

NIMASA (2020) COVID-19 Communique, 29 March 2020. https://nimasa.gov.ng/covid-19-nimasa-bansinternational-vessels-without-thermal-screening-facilities/. Accessed 17 Aug 2020.

Notteboom TE, Haralambides HE (2020) Port management and governance in a post-COVID-19 era: quo vadis? Marit Econ Logistics 22:329-352. https://doi.org/10.1057/s41278-020-00162-7. 
Notteboom, T.E. and Pallis, T. 2020. IAPH-WPSP Port Economic Impact Barometer. 23 July 2020. https:// www.s/ustainableworldports.org/wp-content/uploads/2020-07-23-COVID19-Barometer-Report.pdf. Browsed 08/09/2020.15.13.

Ports Management Association of West and Central Africa (PMAWCA) (2020). Interview published on 26 June 2020, PMAWCA's Chairman Gives His Opinion on Covid-19 And Impacts on The Port Activities. https://agpaoc-pmawca.org/2020/06/26/pmawcas-chairman-gives-his-opinion-on-covid-19-and-impactson-the-port-activities/. Accessed 17 Aug 2020.

Prins, B (2020). Piracy is on the rise, and coronavirus could make it worse. https:/www.weforum.org/agenda/ 2020/05/global-sea-piracy-coronavirus-covid19/. Published on 15 May 2020. Browsed 29/09/2020. 13. 41 .

Ralby, I.M. 2020. Navigating maritime governance challenges and the future of the global economy. Diplomatic Courier, 5th September 2020. https:/www.diplomaticourier.com/posts/navigating-maritimegovernance-challenges-and-the-future-of-the-global-economy. Browsed 07.09.2020, 14.29.

Rendon M, Sanchez L (2020) Covid-19 in Venezuela: how the pandemic deepened a humanitarian crisis. September 23, 2020. https://www.csis.org/analysis/covid-19-venezuela-how-pandemic-deepenedhumanitarian-crisis. Accessed 15 Oct 2020.

Republic of Seychelles (2018) Seychelles blue economy: strategic policy framework and roadmap - charting the future (2018-2030)

The Mombasa Port \& Northern Corridor Community Charter (2020) 2018-2024. https://kma.go.ke/index.php/ mombasa-port-community-charter. Accessed 30 Nov 2020.

Turner, J. (2020). Emission impossible: how the Covid-19 crisis is impacting IMO 2020 enforcement. www. ship-technology.com. Published on 11 August 2020, updated August 24th, 2020 11:04. Browsed 28/09/ 2020. 14.48 .

Twining G (2020) Safety at Sea. COVID-19 to spur on further digitalisation for shipping industry. June 11, 2020. https://safetyatsea.net/news/2020/covid-19-to-spur-on-further-digitalisation-for-shipping-industry/. Accessed 16 Oct 2020.

UNCTAD (2019). Review of Maritime Transport 2019 - sustainable shipping (UNCTAD/RMT/2019).

United Nations (2020). Statement attributable to the Spokesman for the Secretary-General on the repatriation of seafarers. 12 June 2020. https://www.un.org/sg/en/content/sg/statement/2020-06-12/statementattributable-the-spokesman-for-the-secretary-general-the-repatriation-of-seafarers. Browsed 10/09/2020. 15.09 .

Valentine H (2020) The Maritime Executive.04-09-2020. automation could aid port operations during pandemic. https://www.maritime-executive.com/editorials/automation-could-aid-port-operations-duringpandemic. Accessed 16 Oct 2020.

Vrancken, P. (2018). Chapter 11: The African perspective on Global Ocean Governance, in Part V: Regional Perspectives on Global Ocean Governance. From: The IMLI Treatise on Global Ocean Governance: Volume I: UN and Global Ocean Governance. Edited By: David Joseph Attard, David M Ong, Dino Kritsiotis. Oxford Scholarly Authorities on International Law (OSAIL). Published in print: 26 July 2018.

Waters, W. (2019). Digitalisation momentum continues to build in container shipping. Lloyds Loading List. Tuesday, 04 June 2019. https:/www.lloydsloadinglist.com/freight-directory/news/Digitalisationmomentum-continues-to-build-in-container-shipping/74392.htm\#.X38NXGgzZPZ. Browsed 08/10/ 2020. 15.01 .

WHO Africa (2020a) 25 February 2020. A second COVID-19 case is confirmed in Africa. https://www.afro. who.int/news/second-covid-19-case-confirmed-africa. Accessed 02 Sep 2020.

WHO Africa (2020b) 17 September 2020. WHO encouraged by South Africa's declining COVID-19 trend. https://www.afro.who.int/news/who-encouraged-south-africas-declining-covid-19-trend. Accessed 23 Sep 2020.

World Development Report (2017). World Development Report 2017: governance and the law. Washington, DC: World Bank. https://oi.org/10.1596/978-1-4648-0950-7. License: Creative Commons Attribution CC BY 3.0 IGO.

World Bank (2020). The African continental free trade area: economic and distributional effects. Washington, DC: World Bank. https://doi.org/10.1596/978-1-4648-1559-1. License: Creative Commons Attribution CC BY 3.0 IGO. https://openknowledge.worldbank.org/bitstream/handle/10986/34139/9781464815591. pdf. Browsed 20/11/2020. 14.04.

World Bank and UNDESA (2017) World Bank; United Nations Department of Economic and Social Affairs (UNDESA). The potential of the blue economy: increasing long-term benefits of the sustainable use of marine resources for small island developing states and coastal least developed countries. World Bank, Washington, DC. (C) World Bank. https://openknowledge.worldbank.org/handle/10986/26843 License: CC BY 3.0 IGO. 
WHO (2020a) Timeline of WHO's response to COVID-19. https://www.who.int/news-room/detail/29-062020-covidtimeline. Accessed 02 Sep 2020.

WHO (2020b) WHO Director-General's opening remarks at the technical briefing on 2019 novel coronavirus to the 146th session of the Executive Board. 4 February 2020. https:/www.who.int/dg/speeches/detail/ who-director-general-s-opening-remarks-at-the-technical-briefing-on-2019-novel-coronavirus. Accessed 02 Sep 2020.

Yao K, Crossley G (2020) Reuters. China's economy has rebounded after a steep slump - but challenges lie ahead. 16 Jul 2020. https://www.weforum.org/agenda/2020/07/chinas-economy-rebounds-after-steepslump-u-s-tensions-weak-consumption-raise-challenges/. Accessed 15 Oct 2020.

Publisher's note Springer Nature remains neutral with regard to jurisdictional claims in published maps and institutional affiliations. 